\title{
Water-Saving Methods in Irrigated Rice Fields in Chanthaburi, Thailand
}

\author{
Bancha Wiangsamut ${ }^{1 *}$, Manoch Koolpluksee ${ }^{1}$, Chaiwat Makornpas ${ }^{1}$, and \\ Maria Evangeline L. Wiangsamut ${ }^{2}$
}

\begin{abstract}
${ }^{I}$ Department of Crop Production and Landscape Technology, Faculty of Agro-Industrial Technology; and ${ }^{2}$ Department of Liberal Arts, Faculty of Social Technology, Rajamangala University of Technology TawanOk Chanthaburi Campus, Chanthaburi 22210, Thailand.

*Corresponding author.Email: timbancha@yahoo.com,bancha_wi@rmutto.ac.th
\end{abstract}

\begin{abstract}
Khao Hawm Mae Paya Tong Dam (KHMPTD) is healthy traditional rice and an attractive rice variety grown in Chanthaburi, Thailand. Due to the increasing water scarcity for rice, there is a need to develop alternative irrigation systems using less water in producing high grain yield. The study aimed to assess grain yield of KHMPTD rice under continuous flooding and alternate wetting and drying irrigation systems with two different seedling ages of transplanted rice. The study was set out following a split-plot design in randomized complete block design. Continuous flooding (CF) and alternate wetting and drying irrigation systems when the perched water is at $10 \mathrm{~cm}$ below soil surface (AWD10) and at $20 \mathrm{~cm}$ below soil surface (AWD20) occupied the main plot treatments whereas the two different seedling ages (12-day old and 25-day old) of KHMPTD rice occupied the subplot treatments. Data gathered were grain yield, irrigation water use, water used per $1 \mathrm{~kg}$ of unmilled rice grain, and water productivity. The results showed that when seedlings were transplanted at 12 days, AWD10 contributed to having the highest grain yield $(6.53 \mathrm{t} / \mathrm{ha})$ without grain yield decline. With this, grain yield increased by $2 \%$ with less irrigation water use (or $43 \%$ water saving) due to only 1,044 liters of water usage to produce $1 \mathrm{~kg}$ of unmilled rice grain. Consequently, water productivity increased up to $83 \%$ compared with $\mathrm{CF}$ when seedlings were transplanted at 12 days (controlled treatment). Through multiple regression analysis, water productivity explains the $99 \%$ of the grain yield under AWD10. Therefore, AWD10 when seedlings were transplanted at 12 days is the best water-saving method for KHMPTD rice production in Chanthaburi, Thailand.
\end{abstract}

Keywords: Alternate wetting and drying, water productivity, irrigation water use, yield, rice, seedling age

\section{INTRODUCTION}

Rice (Oryza sativa L.) is the major stable food in Thailand and it has been the mainstay of Thai agriculture and other Asian counties. It is also one of the most important food crops in the world and is consumed by more than three billion people [1]. The world population will grow to 8.3 billion in 2030, and 9.3 billion in 2050 . Increasing demand for rice with declining resources base (land, water) is a challenging research work; it is estimated that the world demand for rice will be 533 million tons of milled rice in 2030 [2]. In 2025, approximately $10 \%$ of irrigated rice will face water scarcity [3]. Declining water availability threatens yield of the irrigated rice ecosystem; thus water-saving methods with increasing yield must be sought [4] and alternate wetting and drying irrigation system must be used [5]. By increasing water productivity, water input reduced up to $35 \%$ compared with continuous flooding, but grain yield decreased $[6,7]$. Soil water is lower than saturated condition decreased rice yield [8]. Water deficit affected plant growth, flowering and grain yield by $21 \%, 50 \%$ and $21 \%$, respectively [9]. Irrigation water use in the alternate wetting and severe drying irrigation regimen (AWSD) was 49.8-56.2\% of that applied to the continuous flooding irrigation regimen (CF) but grain yield significantly decreased in AWSD [10]. Maximal water use is up to 5,000 liters to produce $1 \mathrm{~kg}$ of unmilled rice grain [11], and alternate wetting and drying (AWD20) became the interesting water saving methods with increasing yield in sandy loam soil [12]. Intermittent irrigation with alternate wetting and drying intervals (AWDI) can save a significant amount of irrigation water $(28 \%)$ without reduced grain yield $\{7.4$ tons per hectare $(\mathrm{t} / \mathrm{h})$ compared with $7.37 \mathrm{t} / \mathrm{h}$ from normal planting with ordinary water management $\}$ [13]. Early transplanting is an appropriate practice to increase grain yield in irrigated rice. Furthermore, plant growth was not affected in the nursery and by transplanting because of young seedling age at transplanting [14]. Younger seedlings and wider spacing have been observed in tillering ability, panicle length, and number of filled grains that finally 
contributed to higher productivity with better grain quality [13].

In Thailand, the total cultivated rice area is 11.50 million hectares with an average of $3.34 \mathrm{t} / \mathrm{ha}$. With this, the rainfed rice ecosystem is 9.61 million hectares with an average grain yield of $2.53 \mathrm{t} / \mathrm{ha}$ whereas the irrigated rice ecosystem is 1.89 million hectares with an average grain yield of $4.14 \mathrm{t} / \mathrm{ha}$. Khao Hawm Mae Paya Tong Dam (KHMPTD) is a healthy traditional rice variety grown in the district of Khaokitchakut in the province of Chanthaburi, Thailand [15]. KHMPTD rice is drought-tolerant. Some authors reported that its yield was between 3.1$4.4 \mathrm{t} / \mathrm{ha}$ when grown in irrigated rice ecosystem. Nowadays, this rice is becoming a famous rice variety for farmers in Chanthaburi, Thailand. The current limiting water in Chanthaburi province shows a critical condition for fresh water. Increasing rice productivity requires either the expansion of rice planting area or an increase in the production per unit area. With the limited availability of cultivated land and water resources, the most effective way to increase grain yield is by selecting the available local rice variety that is tolerant to the drought-growing condition such as KHMPTD rice variety together with the development of alternate wetting and drying irrigation methods (AWDs) that can cut down water supply for rice cultivation, and with greater grain yield potential by managing the proper seedling ages.

The study aimed to assess grain yield of KHMPTD under continuous flooding irrigation and alternate wetting and drying irrigation systems with transplanting the young seedlings at 12 days and old seedlings at 25 days.

\section{MATERIALS AND METHODS}

The experiment was conducted at Rice Experiment Station of Rajamangala University of Technology Tawan-Ok at Chanthaburi Campus, Chanthaburi, Thailand, from August to December 2016. The study was set out following a split-plot design [16]. Three irrigation methods: continuous flooding $(\mathrm{CF})$, alternate wetting and drying when the perched water is at $10 \mathrm{~cm}$ below soil surface (AWD10), and alternate wetting and drying when the perched water is at $20 \mathrm{~cm}$ below soil surface (AWD20) occupied the mainplot treatments. Two seedling ages of KHMPTD rice occupied the subplot treatments: when transplanted by young seedlings at 12 days (S12) and by old seedlings at 25 days (S25). Six treatment combinations with 4 replications comprised of CFxS12 (a controlled treatment), CFxS25, AWD10xS12, AWD10xS25, AWD20xS12, and AWD20xS25.

In $\mathrm{CF}$ plots, the standing water was maintained between $2 \mathrm{~cm}$ and $10 \mathrm{~cm}$ above soil surface and it was imposed at the first day of transplanting until just 2 weeks before harvest. In AWD10 and AWD20 plots, the standing water was maintained on the first 5 days after transplanting to recover from transplanting shock and then the rice plants were subjected to AWD soil moisture condition known as AWD10 and AWD20 cycles, monitored through the installed porous PVCs' reading. In each time of irrigation, the ponded water level was at $10 \mathrm{~cm}$ above soil surface in AWD10 and AWD20 plots. These AWD cycles were made until the plants flowered. Then, the standing water in AWD10, AWD20, and CF plots was maintained until just 2 weeks before harvest; it was drained to stimulate the physiological maturity and eased to harvest. The prepared rice seedlings of S12 and S25 were transplanted in the sandy loam soil in $\mathrm{CF}$, AWD10, and AWD20 plots at plant spacing of $25 \mathrm{~cm}$ x $25 \mathrm{~cm}, 1$ seedling/hill. The $15-15-15$ basal chemical fertilizer $\left(46.875 \mathrm{~kg} \mathrm{~N} / \mathrm{ha}, 46.875 \mathrm{~kg} \mathrm{P}_{2} \mathrm{O}_{5} / \mathrm{ha}\right.$, and $46.875 \mathrm{~kg} \mathrm{~K} \mathrm{~K}_{2} \mathrm{O} / \mathrm{ha}$ ) was applied just a day before transplanting, and then topdressing chemical fertilizer of 46-0-0 (Urea) (or $86.25 \mathrm{~kg} \mathrm{~N} / \mathrm{ha}$ ) was equally split and applied in 2 stages: at tillering stage $(43.125 \mathrm{~kg}$ $\mathrm{N} / \mathrm{ha}$ ) and at panicle initiation stage (43.125 kg N/ha) based on the chlorophyll meter (SPAD) readings [12]. Hand weeding was done as necessary.

At maturity stage, or 130 days after sowing, grain yield at $14 \%$ moisture content was determined from the harvest area of $5 \mathrm{~m}^{2}$ corresponding to 32 hills per plot in a unit of ton per hectare (t/ha) basis.

The volume of rain water $\left(14,872 \mathrm{~m}^{3} / \mathrm{ha}\right)$, counted from the period of land preparation until just 2 weeks before harvest, was collected from a round concrete pipe with $120 \mathrm{~cm}$ in diameter and $40 \mathrm{~cm}$ tall and was then computed to be the volume of rain water use in the unit of cubic meter per hectare basis. The value readings of irrigation water use only $\left(\mathrm{m}^{3} / \mathrm{ha}\right)$ were done through a flow meter connected to an electric water pump. Water used (L) per $1 \mathrm{~kg}$ of unmilled rice grain was computed from the ratio of the irrigation water use only per unit area to grain yield per unit area. Water productivity (WP) $\left(\mathrm{kg} / \mathrm{m}^{3}\right)$ was computed from the ratio of the total grain yield per unit area to the total irrigation water use only per unit area.

All parameters were analyzed through statistical analysis system program. Treatments means were compared using the Duncan's multiple range test at the 0.05 probability level. Relationships of grain yield with water parameters were determined through stepwise multiple regression analysis.

\section{RESULTS AND DISCUSSION}

3.1. Grain yield, irrigation water use, water used per $1 \mathrm{~kg}$ of unmilled rice grain, and water productivity

Grain yield, irrigation water use, water used per $1 \mathrm{~kg}$ of unmilled rice grain, and water productivity were significantly influenced by the irrigation method and seedling age (Tables 1, 2, 3 and 4). With these, it was only AWD10xS12 that increased grain yield (6.53 t/ha) by $2 \%$ without sacrificing on grain yield with less irrigation water use (or $43 \%$ water saving) due to only 1,044 liters of water usage to produce 1 $\mathrm{kg}$ of unmilled rice grain and consequently water productivity $\left(0.99 \mathrm{~kg} / \mathrm{m}^{3}\right)$ increased up to $83 \%$ 
compared with CFxS12, a controlled treatment. Through stepwise multiple regression analysis, the water productivity has the most significant influence on grain yield. In AWD10 plots the water productivity was the parameter that significantly determined grain yield while in S12 plots the water used per $1 \mathrm{~kg}$ of unmilled rice grain was the parameter that significantly determined grain yield. The multiple regression equations are as follows:

Grain yield ${ }_{(\mathrm{AwD} 10)}=-1.3589+4.6424($ water productivity) (1) $\mathrm{R}^{2}=0.99 *$

Grain yield $_{(\mathrm{S} 12)}=6.3900-0.0071$ (water used per 1 $\mathrm{kg}$ of unmilled rice grain) (2) $\quad \mathrm{R}^{2}=0.98^{*}$

Water productivity explains $99 \%$ of the grain yield in AWD10 as indicated in equation (1). The positive coefficient values indicate that by increasing water productivity, yield also increases. Grain yield when transplanted by $\mathrm{S} 12$ can be explained by the water used per $1 \mathrm{~kg}$ of unmilled rice grain with $98 \%$ accuracy as shown in equation (2). The negative coefficient value indicates that by reducing water used to produce $1 \mathrm{~kg}$ of unmilled rice, grain yield increases when transplanted by $\mathrm{S} 12$. Similar to Chapagain and Yamaji [13], the intermittent irrigation with AWDI can save a substantial amount of irrigation water without sacrificing on grain yield and synergistic effects of younger seedlings and wider spacing noticeable in tillering ability, panicle length, and number of filled grains that ultimately led to higher productivity with better grain quality. While the significantly minimal irrigation water use $\left(3,081 \mathrm{~m}^{3} / \mathrm{ha}\right)$ with $74 \%$ water saving under AWD20xS12 was noticed, only 525 liters of water to produce $1 \mathrm{~kg}$ of unmilled rice grain, and increased water productivity $\left(1.91 \mathrm{~kg} / \mathrm{m}^{3}\right)$ up to $254 \%$ but consequently $9 \%$ grain yield decreased, compared with that of CFxS12. Likewise, grain yields under CFxS25 (3.99 t/ha), AWD10xS25 (4.69 t/ha), and AWD20xS25 (4.87 t/ha) were significantly lower by $2.44 \mathrm{t} / \mathrm{ha}(38 \%), 1.74 \mathrm{t} / \mathrm{ha}(27 \%)$, and $1.56 \mathrm{t} / \mathrm{ha}$ (24\%), respectively, than that of CFxS12 mainly due to the seedling age (S25) in CF, AWD10, and AWD20. Yet, each irrigation method with S25 had substantially higher irrigation water use and water used to produce $1 \mathrm{~kg}$ unmilled rice grain that resulted in the reduction of water productivity compared with S12 (Tables 1, 2, 3, and 4).

Table 1 Grain yield (t/ha)

\begin{tabular}{|c|c|c|c|}
\hline \multirow{2}{*}{$\begin{array}{c}\text { Irrigation method } \\
(\mathbf{I M})\end{array}$} & $\mathbf{2}$ & \multirow{2}{*}{ Mean $^{3 /}$} \\
\cline { 2 - 3 } & $\mathbf{S 1 2}$ & $\mathbf{S 2 5}$ & $5.21 \mathrm{a}$ \\
\hline $\mathrm{CF}$ & $6.43^{1 / \mathrm{a}}$ & $3.99 \mathrm{c}$ & $5.61 \mathrm{a}$ \\
\hline $\mathrm{AWD10}$ & $6.53 \mathrm{a}$ & $4.69 \mathrm{c}$ & $5.38 \mathrm{a}$ \\
\hline $\mathrm{AWD} 20$ & $5.88 \mathrm{ab}$ & $4.87 \mathrm{bc}$ & \\
\hline $\mathrm{Mean}^{2 /}$ & $6.28 \mathrm{a}$ & $4.52 \mathrm{~b}$ & \\
\hline
\end{tabular}

1/in the table of IMxS means with the different letter is significantly different $(\mathrm{P}<0.05)$

2/in the column of $\mathrm{S}$ means with the different letter is significantly different $(\mathrm{P}<0.05)$

${ }^{3 /}$ in the row of IM means with the different letter is significantly different $(\mathrm{P}<0.05)$

Table 2 Irrigation water use $\left(\mathrm{m}^{3} / \mathrm{ha}\right)$

\begin{tabular}{|c|c|c|c|}
\hline \multirow{2}{*}{$\begin{array}{c}\text { Irrigation method } \\
(\text { IM) }\end{array}$} & $\mathbf{2}$ & \multirow{2}{*}{ Seedling age (S) } & \multirow{2}{*}{ Mean $^{3 /}$} \\
\cline { 2 - 3 } & $\mathbf{S 1 2}$ & $15,447 \mathrm{a}$ & $13,622 \mathrm{a}$ \\
\hline CF & $6,686 \mathrm{~d}$ & $7,837 \mathrm{c}$ & $7,262 \mathrm{~b}$ \\
\hline AWD10 & $3,081 \mathrm{e}$ & $3,453 \mathrm{e}$ & $3,267 \mathrm{c}$ \\
\hline Mean $^{2 /}$ & $7,188 \mathrm{~b}$ & $8,912 \mathrm{a}$ & \\
\hline
\end{tabular}

1/in the table of IMxS means with the different letter is significantly different $(\mathrm{P}<0.05)$

2/in the column of $\mathrm{S}$ means with the different letter is significantly different $(\mathrm{P}<0.05)$

${ }^{3 /}$ in the row of IM means with the different letter is significantly different $(\mathrm{P}<0.05)$ 
Table 3 Water used per $1 \mathrm{~kg}$ of unmilled rice grain $(\mathrm{L} / \mathrm{kg})$

\begin{tabular}{|c|c|c|c|}
\hline \multirow{2}{*}{$\begin{array}{c}\text { Irrigation method } \\
(\mathbf{I M})\end{array}$} & $\mathbf{2}$ & \multirow{2}{*}{ Mean $^{3 /}$} \\
\cline { 2 - 4 } & $\mathbf{S 1 2}$ & $\mathbf{S 2 5}$ & $2,860 \mathrm{a}$ \\
\hline CF & $1,836^{1 / \mathrm{b}}$ & $3,883 \mathrm{a}$ & $1,360 \mathrm{~b}$ \\
\hline AWD10 & $1,044 \mathrm{c}$ & $1,676 \mathrm{~b}$ & $622 \mathrm{c}$ \\
\hline AWD20 & $525 \mathrm{~d}$ & $718 \mathrm{~d}$ & \\
\hline Mean $^{2 /}$ & $1,135 \mathrm{~b}$ & $2,093 \mathrm{a}$ & \\
\hline
\end{tabular}

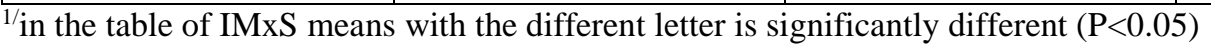

2/in the column of $\mathrm{S}$ means with the different letter is significantly different $(\mathrm{P}<0.05)$

3/in the row of IM means with the different letter is significantly different $(\mathrm{P}<0.05)$

Table 4 Water productivity $\left(\mathrm{kg} / \mathrm{m}^{3}\right)$

\begin{tabular}{|c|c|c|c|}
\hline \multirow{2}{*}{$\begin{array}{c}\text { Irrigation method } \\
(\text { IM) }\end{array}$} & \multicolumn{2}{|c|}{ Seedling age (S) } & \multirow{2}{*}{ Mean $^{3 /}$} \\
\cline { 2 - 3 } & $\mathbf{S 1 2}$ & $\mathbf{S 2 5}$ & $0.40 \mathrm{c}$ \\
\hline CF & $0.54 \mathrm{de}$ & $0.26 \mathrm{e}$ & $0.80 \mathrm{~b}$ \\
\hline AWD10 & $0.99 \mathrm{c}$ & $0.60 \mathrm{~d}$ & $1.67 \mathrm{a}$ \\
\hline AWD20 & $1.91 \mathrm{a}$ & $1.42 \mathrm{~b}$ & \\
\hline Mean $^{2 /}$ & $1.15 \mathrm{a}$ & $0.76 \mathrm{~b}$ & \\
\hline
\end{tabular}

1/in the table of IMxS means with the different letter is significantly different $(\mathrm{P}<0.05)$

$2 /$ in the column of $\mathrm{S}$ means with the different letter is significantly different $(\mathrm{P}<0.05)$

3/in the row of IM means with the different letter is significantly different $(\mathrm{P}<0.05)$

As the young seedlings of Khao Hawm Mae Paya Tong Dam rice variety were transplanted at 12 days (S12), grain yield improved significantly higher by $1.76 \mathrm{t} / \mathrm{ha}(39 \%)$ than that of old seedlings when transplanted at 25 days (S25) (Table 1). Irrigation water use, water used per $1 \mathrm{~kg}$ of unmilled rice grain, and water productivity were affected by seedling age; S12 contributed to having significantly lower irrigation water use and lower water used per $1 \mathrm{~kg}$ unmilled rice grain with higher water productivity than S25 (Tables 2, 3, and 4). Similarly, early transplanting for rice genotypes had a faster tiller emergence by 15 days than late transplanting. Early transplanting improved grain yield, up to $10 \%$ of hybrids and IR72 when seedlings were transplanted at 7 days, and up to $78 \%$ of the new plant type when seedlings were transplanted at 14 days [17]. Likewise, younger seedlings increased leaf area and subsequently increased photosynthetic activity through increased biomass production as a major portion of photosynthates accounted for dry matter [18]. Large leaf area index (LAI) is associated with high grain yield of rice [19]. Young seedlings contributed to having more leaf area covering ground area led to low sunlight penetration on ponding water in rice fields, and consequently low evaporation of irrigated water from the rice fields hence less irrigation water use, low water used to produce $1 \mathrm{~kg}$ of unmilled rice grain, high water productivity. All these factors therefore contributed to having high grain yield at S12 compared with those at S25.

Grain yields under AWD10 and AWD20 were slightly higher than $\mathrm{CF}$, even though their grain yields (5.21-5.61 t/ha) were not significantly different under the three irrigation methods (Table 1). Irrigation water use and water used per $1 \mathrm{~kg}$ unmilled rice grain were significantly influenced by the irrigation methods as AWD20 and AWD10 had less irrigation water use and less water used to produce 1 $\mathrm{kg}$ of unmilled rice grain than CF (Tables 2 and 3). Water productivity was influenced by the irrigation method as AWD20 gave the significantly highest water productivity followed by AWD10, compared with CF (Table 4). By increasing water productivity, grain yield slightly increased by $3-8 \%$ under AWD20 and AWD10, and irrigation water input reduced up to 47-76\%, compared with CF (Tables 1, 2 and 4). Similarly, AWD increased grain yield by $15-28 \%$, and contributed to greater water saving by $20-35 \%$, and increased water productivity from $0.65-0.82$ to $1.18-1.50 \mathrm{~kg} / \mathrm{m}^{3}$ after the application of AWD, while grain yield increased by $15-28 \%[20,21]$. Correspondingly, by keeping a significant depth of water throughout the season, it is not important for high grain yields. The water normally used in irrigated rice fields during the dry season is approximately $40-45 \%$ to keep the soil saturated for the entire growing season, without sacrificing on 
grain yield [22]. The increase in water productivity $\left(1.26 \mathrm{~kg} / \mathrm{m}^{3}\right)$ under AWD compared with that of CF $\left(0.96 \mathrm{~kg} / \mathrm{m}^{3}\right)$ was also cited [23]. In the same way, when maintaining a very thin layer of water at saturated soil condition, or alternate wetting and drying, it could reduce the quantity of water used by $40-70 \%$ compared with continuous shallow submergence, without sacrificing on grain yield [24, $25,26]$. Irrigation water use reduced by $20-50 \%$ for non-flooded rice compared with flooded rice, with the difference depends on rainfall, soil type and water management practices, and grain yields for nonflooded rice decreased proportionally with the reduction of water applied due to increased water stress to the rice plant $[27,28]$.

\section{CONCLUSION}

It is therefore concluded that alternate wetting and drying irrigation system when seedlings were transplanted at 12 days (AWD10xS12) contributed to having the highest grain yield (6.53 t/ha) without grain yield decline. Grain yield under AWD10xS12 increased 2\% with less irrigation water use (43\% water saving) due to only 1,044 liters of water used to produce $1 \mathrm{~kg}$ of unmilled rice grain. Consequently, water productivity increased up to $83 \%$ compared with the controlled treatment, continuous flooding when seedlings were transplanted at 12 days ( $\mathrm{CFxS} 12)$. Water productivity explains the $99 \%$ of the grain yield under AWD10.

\section{ACKNOWLEDGMENT}

The authors would like to offer particular thanks to Rajamangala University of Technology Tawan-Ok for the financial support and allowing the use of the Rice Experiment Station for the study.

\section{REFERENCES}

[1] N. K. Fageria, 'Yield physiology of rice', J Plant Nutr., vol. 30, no. 6, pp. 843-879, 2007.

[2] J. Bruinsma, 'World agriculture: towards 2015/2030 an FAO perspective', Earthscan Pub. Ltd., London, 2003.

[3] B. A. M. Bouman, L. Feng, T. P. Tuong, G. Lu, H. Wang, and Y. Feng, 'Exploring options to grow rice under water-short conditions in northern China using a modeling approach II: Quantifying yield, water balance components, and water productivity', Agric. Water Manag., vol. 88, no. 1-3, pp. 23-33, 2007.

[4] L. C. Guerra, S. I. Bhuiyan, T. P. Tuong, and R. Barker, 'Producing more rice with less water from irrigated systems', International Water Management Institute (SWIM Paper 5), Colombo, Sri Lanka, 1998.
[5] D. F. Tabbal, B. A. M. Bouman, S. I. Bhuiyan, E. B. Sibayan, and M. A. Sattar, 'On-farm strategies for reducing water input in irrigated rice: Case studies in the Philippines', Agric. Water Manag., vol. 56, no. 2, pp. 93-112, 2002.

[6] A. Borell, A. Garside, and S. Fukai, 'Improving efficiency of water use for irrigated rice in a semiarid tropical environment', Field Crops Res., vol. 52, no. 3, pp. 231-248, 1997.

[7] J. Lu, T. Ookawa, and T. Hirasawa, 'The effects of irrigation regimes on the water use, dry matter production and physiological responses of paddy rice', Plant Soil, vol. 223, pp. 207-216, 2000.

[8] T. P. Tuong, and B. A. M. Bouman, 'Rice production in water-scarce environments', in: W. Kijne, R. Barker, and D. Molden (Eds.), 'Water productivity in agriculture: Limits and opportunities for improvement', $C A B$ International., Manila, Philippines, 2003.

[9] H. Pirdashti, Z. T. Sarvestani, G. Nematzadeh, and A. Ismail, 'Study of water stress effects in different growth stages on yield and yield components of different rice (Oryza sativa L.) cultivars', Australian Society of Agronomy Inc., Warragul, 2004.

[10] G. Chu, T. Chen, S. Chen, C. Xu, X. Zhang, and D. Wang, 'The effect of alternate wetting and severe drying irrigation on grain yield and water use efficiency of Indica-japonica hybrid rice (Oryza sativa L.)', Food Energy Secur., vol. 7, no. 2, pp. 1-20, 2018.

[11] R. P. Cantrell, and G. P. Hettel, 'New challenges and technological opportunities for rice-based production systems for food security and poverty alleviation in Asia and the Pacific', Paper presented at the FAO Rice Conference, 12-13 February 2004, FAO, Rome, Italy, pp. 1-16, 2004, Accessed: Aug. 10, 2020. [Online]. Available: http://www.fao.org/rice2004/en/pdf/cantrell.pdf.

[12] B. Wiangsamut, T. Lafarge, and T. C. Mendoza, 'Water productivity of 2 rice genotypes grown in different soil textures and irrigated through continuous flooding and alternate wetting and drying irrigation methods', IJAT, vol. 9, no. 6, pp. 1545-1560, 2013.

[13] T. Chapagain, and E. Yamaji, 'The effects of irrigation method, age of seedling and spacing on crop performance, productivity and water-wise rice production in Japan', Paddy Water Environ., vol. 8, no. 1, pp. 81-90, 2010, doi: 10.1007/s10333-009-0187-5.

[14] E. Pasuquin, T. Lafarge, and B. Tubana, 'Transplanting young seedlings in irrigated rice fields: Early and high tiller production enhanced grain yield', Field Crops Res., vol. 105, no. 1-2, pp. 141-155, 2008

[15] W. Lertnimitmongkol, and N. Mongkontanawat, 'The Development of Khao Hawm Mae Paya Tong Dam Black Rice (Oryza sativa L.) Bar mixed with Fried Pisang Mas (Musa Sapientum)', RMUTSV, vol. 12, no. 2, pp. 362-373, 2020. 
[16] K. A. Gomez, and A. A. Gomez, 'Statistical Procedures for agricultural research', John Wiley and Sons, New York, 1984.

[17] E. Pasuquin, B. Tubana, J. Bertheloot, and T. Lafarge, 'Impact of early transplanting on tillering and grain yield in irrigated rice', ICSC2004 Conf. Proc., Brisbane, 2004, Accessed: Apr. 5, 2020. [Online]. Available: http://www.cropscience.org.au/icsc2004/poster/2 13/864_pasuquine.htm\#TopOfPage.

[18] K. Senthilkumar, 'Productivity of hybrid rice under water saving irrigation and in situ weed incorporation', Tamil Nadu Agricultural University, 2002.

[19] C. Ju, R. J. Buresh, Z. Q. Wang, H. Zhang, L. J. Liu, J. C. Yang, and J. H. Zhang, 'Root and shoot traits for rice varieties with higher grain yield and higher nitrogen use efficiency at lower nitrogen rates application', Field Crops Res., vol. 175, pp. 47-55, 2015.

[20] Z. Mao, 'Principle and technique of water saving irrigation for rice', Wuhan University of Hydraulic and Electric Engineering, 1993.

[21] Z. Mao, 'Environmental impact of water-saving irrigation for rice, ICID/FAO Proc., Rome, pp. 141-146, 1996.

[22] S. I. Bhuiyan, and T. P. Tuong, 'Water use in rice production: Issues, research opportunities and policy implications', International Water Management Institute, Geneva, 1995.
[23] V. Anbumozhi, E. Yamaji, and T. Tabuchi, 'Rice crop growth and yield as influenced by changes in ponding water depth, water regime and fertigation level'. Agric. Water Manag., vol. 37, no. 3, pp. 241-253, 1998

[24] S. Hatta, 'Water consumption in paddy field and water saving rice culture in the tropical zone', JPN J TROP AGR, vol. 11, no. 3, pp. 106-112, 1967.

[25] D. F. Tabbal, R. M. Lampayan, and S. I. Bhuiyan, 'Water-efficient irrigation technique for rice', in: V. V. N. Murty, and K. Koga (Eds), 'Soil and water engineering for paddy field management', Proc. of the international workshop on soil and water engineering for paddy field management, Bangkok, pp.146-159, 1992.

[26] C. B. Singh, T. S. Aujla, B. S. Sandhu, and K. L. Khera, 'Effects of transplanting data and irrigation regime on growth, yield and water use in rice (Oryza sativa) in northern India', Indian J. Agric. Sci., vol. 66, pp. 137-141, 1996.

[27] S. Keisuke, E. Yamaji, S. Sato, P. S. Budhiharto, and M. Mizoguchi, 'Sustainability of system of rice intensification: benefits of SRI focusing on effects of intermittent irrigation on yield increase and water savings', PAWEES 2007 Conf. Proc., Seoul, pp. 25-37, 2007.

[28] G. Davids, 'Use of the capital intensive irrigation systems in rice', Davids Engineering Inc. California, 1998. 